VanderMolen, G.E., C.H. Beckman \& E. Rodehorst. 1987. The ultrastructure of tylose formation in resistant banana following inoculation with Fusarium oxysporum f. sp. cubense. Physiol. Mol. Plant Path. 31: 185-200.

Wisniewski, W., E. Ashworth \& K. Schaffer. 1987. The use of lanthanum to characterize cell wall permeability to deep su- percooling and extracellular freezing in woody plants. II. Intrageneric comparisons between Betula lenta and Betula papyrifera. Protoplasma 139: 105-116.

Wooding, F.B.P. \& D.H. Northcote. 1965. An anomalous wall thickening and its possible role in the uptake of stem-fed tritiated glucose by Pinus picea. J. Ultrastruct. Res. 12: 463-472.

\title{
REVIEW AND ANNOUNCEMENT
}

The plant-book - A portable dictionary of the higher plants. D. J. Mabberley, xii +706 pp., 1987. Cambridge University Press, Cambridge, New York. Price: UK£ 20.00 (soft cover).

For most, if not all curators of wood collections H.K. Airy Shaw's revised editions of J.C. Willis's Dictionary of the flowering plants and ferns has been an indispensable tool for storing their specimens in a botanically sound place. The last of those editions dates from 1973, and meanwhile botany has progressed and Mr. Airy Shaw has passed away. We must therefore be grateful to Dr. Mabberley for producing 'The plant-book', which combines the virtues of the original Willis Dictionaries in providing information on vernacular names and uses of plants (including end uses of wood) with an update on the Latin family and generic names of flowering plants and ferns, with concise information on number of species and geographical distribution. Apart from the main body of plant names and family descriptions, the book contains a brief biography of J.C. Willis, a survey of Cronquist's system for the arrangement of the angiosperms, a list of bibliographical sources, and lists of abbreviations used, of which especially those of authors' names will be very useful.

With its price of $£ 20.00$ and 703 pages of small print, this book is a bargain. It should be present on the shelves of each xylarium curator. Incorporation of the welcome infor- mation on common English names and uses compensates for the omission of old and obsolete generic names. One is thus advised not to throw away the 8th edition of Willis's dictionary, because in institutional wood collections these obsolete names sometimes seem to have an eternal life - alas. Apart from its usefulness for curatorial work, "The plantbook' has of course much wider uses as a vademecum of botanical names and the plants they represent. - Pieter Baas.

Himalayan plants. Vol. 1. H. Ohba and S. B. Malla (eds.), 500 pp., illus., 1988. University of Tokyo Press (distributors for the New World: Columbia University Press, Irvington, NY; for Europe, the Middle East, and Africa: Academic \& University Publishers, London; for Asia: Toppan Co., Singapore). Price US\$225.50.

This first instalment of a series to include 5 volumes dealing with the flora of the Himalayas, is announced here for its extensive chapter of 40 pages and 43 plates on the wood anatomy of 41 species of gymnosperm and angiosperm woods by Mitsuo Suzuki and Shuichi Noshiro. These woods, part of a collection made during expeditions to central Nepal in 1983 and 1985, are described in great anatomical detail, as a starting point for our knowledge of the wood anatomical diversity in this poorly studied, interesting flora. We hope for many additions to this useful study. 